\title{
Postharvest fruit spoilage bacteria and fungi associated with date palm (Phoenix dactylifera $L$ ) from Saudi Arabia
}

\author{
Amal A. Al Hazzani, Afaf I. Shehata*, Humaira Rizwana, Nadine M. S. Moubayed, \\ Ali A. Alshatwi, Anjana Munshi and Gehan Elgaaly
}

Department of Botany and Microbiology, College of Science, King Saud University, P. O. Box - 22452, Riyadh, 11495,Kingdom of Saudia Arabia.

Accepted 18 November, 2013

\begin{abstract}
Date fruits are consumed as traditional and ideal food in Saudi Arabia. It provides a wide range of essential nutrients and potential health benefits. Twelve (12) most consumed varieties of date fruits and their seeds available in the open markets of Riyadh, Medina and Kharj were screened for the presence of bacteria and fungi. Our study reveals that these fruits carry a heavy load of both fungal and bacterial pathogens. The variety Sukhari was found to be the most contaminant fruit with fungi while the bacterial contamination was highest in the variety Mabroon. The Genus Aspergillus was represented by seven species, amongst which Aspergillus niger was the most predominant fungi. Potential pathogens like Staphylococcus aureus and Escherichia coli were isolated besides six species of the genus Bacillus. Fruits were more contaminated than their seeds.
\end{abstract}

Key words: Date fruits, seed borne, fruit spoilage, open markets.

\section{INTRODUCTION}

The date palm (Phoenix dactylifera $L$ ) is one of the oldest fruit trees of the world and is closely associated with the life of the people in the Middle East including the Kingdom of Saudi Arabia since ancient times. It has religious values as well as cultural importance. In Saudi Arabia, date palm is the most important cash and fruit crop grown in different regions. It produces yearly about 900 thousand tones and ranks as the third largest producer in the world (FAO, 2008). Saudi Arabia, ranked number one among the date producers and exporting countries in the world, where it produces 7170 tons of date fruits annually (Al-Showiman and BaOsman, 1992). Most of the produce in Saudi Arabia is consumed locally as human food, while the rest is exported. Saudi Arabia is also a genetic centre of date-palm trees and there are more than 400 different cultivars of fruiting date palm of economic value (Fayadh and Al Showiman, 1990).

Date fruits contain a high percentage of carbohydrate (44.88\%), protein (2.3-5.6) and dietry fiber (6.4-1.5\%). The fat percentage reach upto $(0.2-0.5 \%)$, including 14 types of fatty acids (Al Kahtani et al., 2011). Date fruits are consumed in many forms and at all stages of the fruit development that is Kimri, Rotab and Tamr. In addition to the direct consumption of the fruit, dates are also utilized in many ways in modern industries (Mustafa et al., 1983; Sawaya et al., 1989; Shinwari, 1993) Therefore special attention is being paid by the government of Saudi Arabia in providing subsidies and price support of low grade varieties (Al Shuaibi, 2011).

In practice, besides bacteria and yeast, molds are 
considered to be the major causative agents of the spoilage of date fruits at all stages of ripening on trees, as well as during storage and processing. Some potential pathogens and mycotoxin producing microbes isolated from date fruits include Staphylococcus aureus, Escherichia coli, species of Aspergillus, Penicillium, Alternaria and Fusarium (Kader, 2007; Hamad, 2008; Hayrettin et al., 2012; Aido et al., 1996, El-Sherbeeny et al., 1985; Abdulsalam et al., 1991).

Our study aims at enumeration of bacteria and fungi, causing spoilage of date fruits and seed borne pathogens from fruits sold as loose dates, in the open markets of Saudi Arabia .It also highlights the risks and awareness of consumption of contaminated fruits which carry mycotoxin producing fungi and potential pathogens. To our knowledge this is the first time that fruit varieties that is Ajwa, Amber, Rabeae and Mashrooq are being screened in Saudi Arabia for the presence of microbes responsible for causing fruit spoilage and also the first report of identification of isolated bacterial strains upto species level.

\section{MATERIALS AND METHODS}

Date fruits grown locally in Saudi Arabia, sold as loose dates in open markets were chosen for the study. Date fruits were collected from open market of Riyadh, Medina and Al Kharj. The varieties choosen were Ajwa, Amber,Barhi, Mashrooq ,Mabroon, Rabeae , Al Segae, Khodary, Khalas, Naboot Sultan, Naboot-Seif and Sukhari

\section{Isolation of Seed-Borne Fungi}

Isolation of seed borne fungi was carried out by Standard blotter method as described by the International Seed Testing Association (ISTA 1976). A total of 50 seeds from each variety were screened. Five seeds per plate from each variety were plated in $13 \mathrm{~cm}$ diameter Petri dishes over moist filter paper and Potato dextrose agar (Oxoid ,UK). The paper was kept moist throughout the experimental period by adding sterile water. Ten replicates were used for each variety. These plates were then incubated at $25 \pm 2^{\circ} \mathrm{C}$ for one week and cultured on potato dextrose agar (Oxoid, UK) for identification.

\section{Isolation of Fungi from date fruits}

Dates fruits were cut into approximately $2 \mathrm{~cm}^{3}$ pieces and five pieces were placed aseptically on Potato Dextrose Agar (PDA Oxoid, UK) and moist filter papers, incubated at $25 \pm 2^{\circ} \mathrm{C}$ for $5-10$ days. Mixed cultures were purified using single spore and maintained on PDA.Ten replicates were used for each variety.

\section{Identification of fungi}

Identification of the purified cultures was done either to generic or the species level according to their appropriate taxonomic key and description (Ellis, 1971; Raper and Fennell, 1965; Ramirez, 1982;
Nelson et al., 1983). Pure cultures of the isolated fungi were maintained at $5^{\circ} \mathrm{C}$.

\section{Bacterial isolation}

Fruits flesh was washed and deseeded; seeds were washed with sterile distilled water, then rinsed with chlorinated water $(2 \%)$ for 1 min and then washed off four times again with sterile distilled water, microbial loads were calculated both from seeds and flesh. Sterilized date fruit samples $(10 \mathrm{~g})$ were aseptically weighed into sterile stomacher bags ( Seward Medical , London ,U.K) with $90 \mathrm{ml}$ sterile $0.1 \%$ peptone water (Oxoid CM9). Samples were then homogenized for 2 mins and a serial dilution 1.1000 were prepared. Aliquots $(0.1 \mathrm{ml})$ of diluted homogenate were then plated on Nutrient Agar plates (N.A, Oxoid) and Plate Count Agar (PCA, Oxoid) in triplicates, plates were incubated at $37^{\circ} \mathrm{C}$ for $24 \mathrm{~h}$ for bacterial enumeration. The mean of the bacterial load obtained from the plates was reported as number of bacteria $/$ plate $/ \mathrm{ml}$ on different media Nutrient agar (N.A, Oxoid) and Plate Count Agar (PCA, Oxoid).

Same procedure as fruits was applied for isolation for seed borne bacteria, besides sterilized seeds were placed ( 5 per plate) on N.A (Oxoid). Plates were incubated at $37^{\circ} \mathrm{C}$ and examined every $24 \mathrm{~h}$ for up to 5 days . Bacterial isolates were randomly selected from outgrowths on and around seeds and streaked on N.A and glucose peptone agar until pure cultures were obtained for characterization and Identification (Collins et al., 2004).

\section{Identification of bacterial isolates}

Identification of bacterial isolates obtained from date fruit varieties (both flesh and seeds) in our study, were characterized and identified by their cultural morphology and biochemical properties (Collins et al .,2004; Cheesebrough, 2000) tentataively. However, further confirmation for gram positive rods was done with the help of API $50 \mathrm{CH} / \mathrm{B}$ galleries while two isolates which were different from the above isolates were identified with the help of morphologyical charactertics and biochemical test alone. Pure cultures of isolates were stored in nutrient broth (N.B, Oxoid) containing 15\% glycerol (Merck) at $-4^{\circ} \mathrm{C}$. Among all the bacteria isolated, only those gram positive, endospore forming rod producing bacteria were selected for further identification according to their carbohydrate fermentation using the API $50 \mathrm{CH} / \mathrm{B}$ galleries at least in duplicate.

Results were recorded after 24 hof incubation at $37^{\circ} \mathrm{C}$. The ultimate identification was ensured by the API web identification software (Biomerieux, France) as indicated by the manufacturer's instruction.

\section{Bacterial Identification by API $50 \mathrm{CH} / \mathrm{B}$ and Biochemical tests}

The phenotypic characterization of those isolates described as gram positive endospore forming long rod obtained, were identified upto genus level as Bacillus. Further biochemical identification were performed by the API $50 \mathrm{CH} / \mathrm{B}$ medium.

\section{RESULTS}

All cultivars of date fruit were contaminated with fungi whereas bacterial population was found in varying numbers and were absent totally in some date fruit varieties. 
Table 1. Percentage occurrence of fungi associated with fruit spoilage of different varieties of date palm.

\begin{tabular}{|c|c|c|c|c|c|c|c|c|c|c|c|c|}
\hline \multirow{2}{*}{ Fungi isolated } & \multicolumn{12}{|c|}{ Date varieties screened } \\
\hline & Ajwa & Amber & Barhi & Khalas & Khodary & Mabroon & Mashrooq & Sukhari & Segae & Naboot Sultan & Naboot Seif & Rabeae \\
\hline Alternaria alternate & 52 & 68 & 80 & 88 & 72 & 58 & 40 & 28 & 18 & 12 & 84 & 68 \\
\hline Aspergillus ellipticus & $\ldots$ & 4 & $\ldots$ & 4 & $\ldots$ & $\ldots$ & $\ldots$ & $\ldots$ & $\ldots$ & $\ldots$ & 12 & $\ldots$ \\
\hline A. flavus & 50 & 54 & 68 & 52 & 42 & 48 & 44 & 38 & 42 & 34 & 42 & 48 \\
\hline A.fumigatus & $\ldots$ & 20 & 30 & 6 & $\ldots$ & 8 & $\ldots$ & 4 & $\ldots$ & 18 & 48 & 24 \\
\hline A.nidulans & $\ldots$ & 22 & 28 & 54 & 24 & 4 & $\ldots$ & 4 & 2 & $\ldots$ & $\ldots$ & $\ldots$ \\
\hline A. niger & 80 & 90 & 88 & 82 & 78 & 76 & 80 & 88 & 66 & 86 & 92 & 82 \\
\hline A.terreus & 54 & 4 & 42 & 52 & 24 & 14 & 18 & 10 & 18 & 12 & 58 & 54 \\
\hline Aspergillus sp. & $\ldots$ & 2 & $\ldots$ & $\ldots$ &.. & 4 & 2 & $\ldots$ & $\ldots$ & $\cdots$ & 2 & $\ldots$ \\
\hline Bipolaris sp & $\ldots$ & $\ldots$ & 28 & 20 & 14 & 12 & 34 & $\ldots$ & 10 & 8 & 14 & 4 \\
\hline Cladosporium cladosporoides & $\cdots$ & $\ldots$ & 4 & 22 & 8 & $\cdots$ & 6 & 6 & 8 & $\cdots$ & 16 & $\ldots$ \\
\hline Curvularia lunata & 2 & 6 & 12 & 34 & 28 & 18 & 4 & 2 & 10 & 6 & 38 & 20 \\
\hline Fusarium monoliforme & $\cdots$ & $\ldots$ & 28 & 38 & 52 & 32 & 14 & 16 & 8 & 6 & 44 & $\ldots$ \\
\hline F.oxysporum & 20 & 54 & 34 & 54 & 68 & 42 & 52 & 22 & 28 & 54 & 66 & 52 \\
\hline F.solani & 20 & 18 & 8 & 12 & 20 & 4 & 8 & 12 & 20 & 14 & 28 & 14 \\
\hline Mucor spp & $\cdots$ & $\ldots$ & 4 & $\ldots$ & $\ldots$ & $\cdots$ & $\cdots$ & 2 & $\ldots$ & 6 & 4 & $\ldots$ \\
\hline Penicillium chrysogenum & 54 & 58 & 80 & 78 & 34 & 32 & 20 & 6 & 82 & 52 & 84 & 82 \\
\hline P.digitatum & $\ldots$ & 8 & 14 & 32 & 2 & 2 & 4 & $\cdots$ & $\cdots$ & $\cdots$ & 12 & 20 \\
\hline P.expansum & $\ldots$ & $\ldots$ & 12 & 2 & $\ldots$ & 4 & 8 & 2 & 4 & $\ldots$ & 6 & 8 \\
\hline Penicillium sp & $\cdots$ & $\cdots$ & 6 & 8 & $\cdots$ & 4 & $\cdots$ & $\cdots$ & $\cdots$ & $\cdots$ & 2 & $\cdots$ \\
\hline Rhizopus stolonifer & 20 & 30 & 74 & 82 & 44 & 14 & 10 & 4 & 6 & 24 & 80 & 72 \\
\hline
\end{tabular}

..., not detected.

\section{Fruit spoilage mycoflora}

A total of 20 species belonging to nine genera were isolated from the flesh of date palm fruits used in our experiment (Table 1). The following fungi were isolated from all the cultivars screened, amongst them Aspergillus niger (81\%) was the most predominant species followed by Alternaria alternate $(55.66 \%), \quad P e n i c i l l i u m$ stolonifer (55.16\%), A. flavus (46.83\%), Fusarium oxysporum (43.83), F. solani (34\%) Rhizopus stolonifer (38.33\%), Aspergillus terreus (30\%),
F.monoliforme (19.83), Curvularia lunata (15\%). Amongst all the nine genera isolated from the date fruits screened, seven species belonged to the genera Aspergillus ,four species belonged to Penicillium, three of Fusarium and one species each belonged to the genus Alternaria, Bipolaris, Cladosporium, Curvularia, Rhizopus and Mucor.

Our results reveal that Sukhari, Khalas ,Barhi, Segae and Amber were the most suspectible cultivar compared to the other cultivars. A. niger was found in high percentages in variety Sukhari (92\%), Amber (90\%) and Barhi (88\%). A maximum of 700 and 32 isolates were isolated from Sukhari followed by 720 from Khalas and 666 isolates from the cultivar Barhi.

\section{Seed borne fungi}

Seed from different cultivars of date palm harboured a total of nine genera belonging to 13 species. A. niger was the most predominant followed by $F$. oxysporum, F. solani, A. flavus, A. alternate and $R$. stolonifer (Table 2). Seeds from 
Table 2. Percentage occurrence of seed borne fungi associated with different varieties of date palm.

\begin{tabular}{|c|c|c|c|c|c|c|c|c|c|c|c|c|}
\hline \multirow{2}{*}{ Fungi isolated } & \multicolumn{12}{|c|}{ Date varieties screened } \\
\hline & Ajwa & Amber & Barhi & Khalas & Khodary & Mabroom & Mashrookh & Sukhari & Sagaei & Naboot Sultan & Naboot Seif & Rabeae \\
\hline Alternaria alternata & 4 & 6 & 12 & 14 & 10 & 2 & 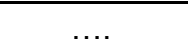 & 16 & 4 & 2 & 14 & 4 \\
\hline A.carbonarius & $\ldots$ & $\ldots$ & 4 & $\ldots$ & $\ldots$ & $\ldots$ & $\ldots$ & $\ldots$ & $\ldots$ & 2 & $\ldots$ & $\ldots$ \\
\hline Aspergillus flavus & 14 & 22 & 18 & 40 & 42 & 10 & 12 & 18 & 8 & 14 & 40 & 38 \\
\hline Aspergillus niger & 24 & 42 & 28 & 36 & 26 & 42 & 36 & 24 & 22 & 38 & 48 & 58 \\
\hline Bipolaris sp & $\ldots$ & $\ldots$ & 8 & $\ldots$ & $\ldots$ & $\ldots$ & $\ldots$ & $\ldots$ & $\ldots$ & $\ldots$ & 18 & $\ldots$ \\
\hline Chaetomium sp & $\ldots$ & $\ldots$ & $\ldots$ & $\ldots$ & 14 & $\ldots$ & & $\ldots$ & $\ldots$ & $\ldots$ & 12 & 4 \\
\hline Dreschlera sp & $\ldots$ & $\ldots$ & 8 & $\ldots$ & $\ldots$ & 4 & $\ldots$ & $\ldots$ & $\ldots$ & $\ldots$ & 16 & \\
\hline F.oxysporum & 12 & 22 & 28 & 60 & 38 & 18 & 14 & 10 & 16 & 12 & 68 & 60 \\
\hline F.solani & 26 & 34 & 18 & 30 & 34 & 24 & 14 & 2 & 38 & 26 & 20 & 28 \\
\hline Penicillium chrysogenum & $\ldots$ & 2 & 8 & $\ldots$ & $\ldots$ & 4 & $\ldots$ & 12 & 10 & $\ldots$ & 6 & $\ldots$ \\
\hline Rhizopus oryzae & 4 & $\ldots$ & 2 & $\ldots$ & $\ldots$ & 2 & $\ldots$ & $\ldots$ & $\ldots$ & 6 & $\ldots$ & $\ldots$ \\
\hline Rhizopus stolonifer & 18 & 8 & 14 & 6 & $\ldots$ & $\ldots$ & $\ldots$ & $\ldots$ & $\ldots$ & 8 & 10 & 4 \\
\hline Trichoderma virde & $\ldots$ & $\ldots$ & 2 & $\ldots$ & $\ldots$ & 2 & $\ldots$ & $\ldots$ & $\ldots$ & $\ldots$ & 4 & $\ldots$ \\
\hline
\end{tabular}

...., Not detected

all the date fruit varieties screened showed the presence of fungi in varying numbers. However A. niger, $F$. oxysporum, F. solani and A. flavus were isolated from all the cultivars screened. Bipolaris sp was reported only from the cultivar Sukhari and Barhi while Chaetomium was found in Khodary,Sukhari and Segae.

\section{Bacterial contamination of fruit and seed of date palm}

Among a total of 30 bacterial isolates form both flesh and seeds of date fruits only 25 could be identified of which all were gram positive rods as confirmed by API and the other two were $S$. aureus and E. coli (Table 3). API ensured that most isolates belong to the genus Bacillus and they were Bacillus subtilis ,Bacillus thurengenesis, Bacillus stearothermophilus, Bacillus brevis, Bacillus mycoides and Bacillus megaterium 2 (Table 4) (API). Bacillus sp. strains, identified with the API $50 \mathrm{CH}$ strips, fermented mostly Glycerol, L-arabinose, D-ribose, D- xylose, L-xylose, Dadonitol, D-galactose, Inositol, amygdalin, arbutin, salicin, D-maltose, D-lactose (bovine origin), Dsaccharose (sucrose), D-trehalose, glycogen and xylitol. All Bacillus sp. were able to ferment Esculin Ferric Citrate.

Maximum bacterial load was found to be associated with the date variety Mabroon, followed by Khalas ,Barhi ,Mashrooq, Sukhari, Khodary, Ajwa , Naboot Sultan Amber, Naboot Seif, Rabeae and the least bacterial count was found the variety Segae. Mabroon showed the presence of $B$. thuringenesis. $B$. subtilis was isolated from all the fruit varieties but varying numbers except Sagae and Rabeae that showed its complete absence. However, it was high in the variety Barhi and Khalas.

The date fruit variety Barhi and Naboot Sultan showed the presence of all the six species of the genus Bacillus that is $B$. subtilis, $B$. thurengenesis, B. stearothermophilus, B. brevis, $B$. mycoides, and B. megaterium. E. coli was present in Khodary and Naboot Sultan only while Rabeae was the only variety which showed the presence of the contaminant $S$. aureus. Among all the date varieties screened for the presence of seed borne bacterial isolates, only two varieties that is Mabroon and Naboot Sultan showed bacterial contamination with $B$. subtilis and $B$. brevis while the rest of them did not yield any growth on the respective media (Table 5). 
Table 3. Biochemical tests performed on Gram positive cocci and Gram negative rods.

\begin{tabular}{lcc}
\hline Biochemical test & Result & Results \\
\hline Gram positive cocci grape like sturcture & 24 & 25 \\
Catalase test & + & - \\
Coagulase test & + & - \\
Mannitol salt agar plate & yellow & - \\
& & \\
Gram negative rods biochemical tests & - & + \\
Methyl Red & - & - \\
Vogues Proskauer & - & - \\
Citrate & - & - \\
Urease & - & Green metallic sheen \\
Eosine Methylene Blue plate & - & Pink \\
MacConkey agar plate & Staphyloccus aureus & Escherishia coli \\
Identification & &
\end{tabular}

\section{DISCUSSION}

Moulds are considered to be the major causative agent of the spoilage of date fruits at all stages of ripening on trees as well as during storage and processing. Both seeds and fruits showed the presence of fungi in varying number. However, fruits were heavily contaminated than seeds. Fungi belonging to the Genus Aspergillus were present in high numbers in dry dates; the most predominant amongst them were the $A$. niger, $A$. flavus $A$. fumigatus and $A$. nidulans. Similar findings were reported by Ragab et al. (2001). Al Sheikh (2009) isolated 10 species of Aspergillus, of them $A$. niger predominated. Our results are also in accordance with Atia ((2011) who isolated $A$. niger as predominant fungi followed by $A$. flavus. A study conducted on date palm fruits collected from Figuig oasis of Morocco also showed A. niger to be the most prevalent of all the fungi isolated. During our study, some dry seeds and fruit of the cultivar Khalas and Sukhari were heavily contaminated with $A$. niger alone.

The predominance of black Aspergilli in dried fruits could be due to the protection provided by their black spores from sunlight and ultraviolet light thereby giving them a competitive advantage in this habitat. Moreover, high sugar concentration and low water activity in dried fruits also assist the development of these fungi because they are xerophilic in nature (lamanaka et al., 2005).

The second most dominant fungi in the fruits was Alternaria alternate followed by Penicillium chrysogenum whereas the second most dominating seed borne fungi was $F$. oxysporum followed by $F$. solani. Presence of Fusarium spp in high numbers from seeds of different date varieties has been reported earlier (Al Sheikh, 2009; Bokhary, 2010). Additionally, Fusarium spp is known to cause Bayoud disease and has also been isolated from leaf rachis from different varieties and from different areas of central region of Saudi Arabia (Al-Shahwan et al., 1997; El-Hassni et al., 2007). C. cladosporoides was isolated in very low numbers in our study.

Other fungal genera like Rhizopus stolonifer, Curvularia lunata, Chaetomium sp, Mucor $s p$ and other fungi were isolated with various frequencies and occurrence .Similar fungal species and many more were reported from different varieties of date fruits and seeds from markets and under different storage conditions from Saudi Arabia (Moore et al., 2011; Atia, 2011; Al Sheikh, 2009; Bokhary, 2010; Hamad, 2012). This high level of mold contamination can be attributed to the fact that dates are harvested in the dry windy months of July -September. Airborne mold spores can easily contaminate the fruits of tall palm trees (Hamad, 2012).

All the date fruit varieties screened, showed varying numbers of bacterial load.

Mabroon, Khalas and Barhi emerged as the most contaminated varieties while Naboot Sultan and and Barhi showed the presence of all the six species of Bacillus isolated during our screening; this could be attributed to moisture content, carbohydrates, nature of solutes, post harvest conditions like storage temperature, ripening stage or the cultivar itself could be considered as the major factors affecting the microbial load and as consequence the shelf life of dates (Rygg et al., 1956; Hasnaoui et al, 2010; Al Jasser,2010).

Isolation of some fungal species from all the samples of date fruit and seeds makes it evident that some molds are generally more tolerant to low water activity levels than bacteria and hence seems to be more persistent in the dry and hot conditions prevailing in the open markets whereas these condition are not conducive for the proliferation of endogenous bacterial flora which is clear from the low incidence of bacterial count from all the date 
Table 4. Profiles of the biochemical tests using API 50CH/B Medium galleries for Identification of Bacillus strains.

\begin{tabular}{|c|c|c|c|c|c|c|c|c|c|c|c|c|c|c|c|c|c|c|c|c|c|c|c|}
\hline Parameter & 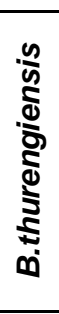 & 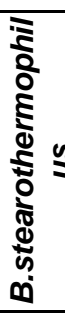 & 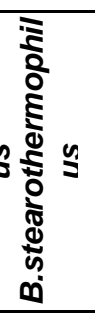 & 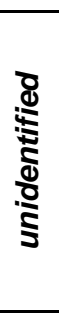 & 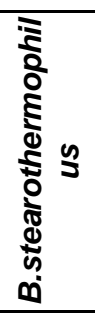 & 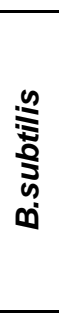 & 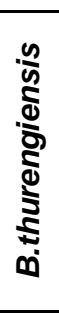 & $\frac{n}{\frac{n}{0}}$ & 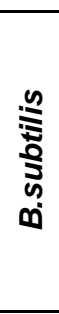 & 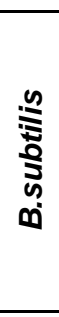 & 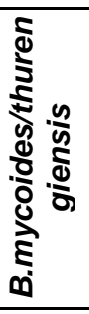 & 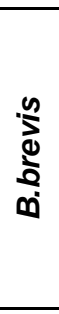 & 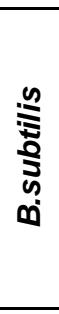 & 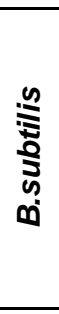 & 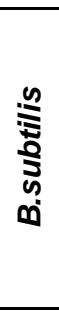 & $\frac{n}{\frac{n}{0}}$ & 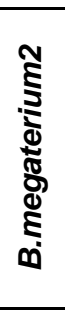 & 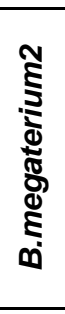 & 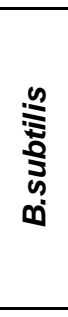 & $\frac{n}{\frac{n}{0}}$ & 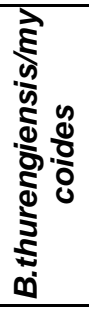 & 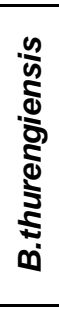 & 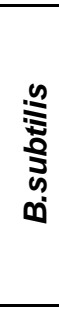 \\
\hline & 1 & 2 & 3 & 4 & 5 & 6 & 7 & 8 & 9 & 10 & 11 & 12 & 13 & 14 & 15 & 16 & 17 & 18 & 19 & 20 & 21 & 22 & 23 \\
\hline 0 Control & - & - & - & & - & - & - & - & - & - & - & - & - & - & - & - & - & - & - & - & - & - & - \\
\hline Glycerol & - & + & + & & - & + & - & - & + & + & - & - & + & + & + & + & - & - & - & + & - & - & + \\
\hline Erythritol & - & - & - & & - & - & - & - & - & - & - & - & - & - & - & - & - & - & - & - & - & - & - \\
\hline D-Arabinose & - & - & - & & - & - & - & - & - & - & - & - & - & - & - & - & - & - & - & - & - & - & - \\
\hline L-Arabinose & - & + & + & & - & + & - & - & + & + & - & - & + & + & + & + & _ & + & + & + & - & - & + \\
\hline D-Ribose & + & + & + & & - & + & - & - & + & + & + & - & + & + & + & + & _- & + & + & + & - & + & + \\
\hline D-Xylose & - & - & - & & - & + & - & - & - & - & - & - & - & + & + & - & - & + & + & + & - & - & - \\
\hline L-Xylose & - & - & - & & - & - & - & - & - & - & - & - & - & - & - & - & - & - & - & - & - & - & - \\
\hline D-Adonitol & - & - & - & & - & - & - & - & - & - & - & - & - & - & - & - & - & - & - & - & - & - & - \\
\hline $\begin{array}{l}\text { Methyl-ß-D- } \\
\text { Xylopyranoside }\end{array}$ & - & - & - & & - & - & - & - & - & - & - & - & - & - & - & - & - & - & - & - & - & - & - \\
\hline D-Galactose & - & - & - & & - & - & - & - & - & - & - & - & - & - & - & - & - & - & - & - & - & - & - \\
\hline D-Glucose & + & + & + & & + & + & + & - & + & + & + & - & + & + & + & + & - & + & + & + & - & + & + \\
\hline D-Fructose & + & + & + & & + & + & + & - & + & + & + & - & + & + & + & + & - & + & + & + & - & + & + \\
\hline D-Mannose & - & + & + & & - & + & - & - & + & + & - & - & + & + & + & + & - & - & _- & + & - & - & + \\
\hline L-Sorbose & - & - & - & & - & - & - & - & - & - & - & - & - & - & - & - & - & - & - & - & - & - & - \\
\hline L-Rhamnose & - & - & - & & - & - & - & - & - & - & - & - & - & - & - & - & - & - & - & - & - & - & - \\
\hline Dulcitol & - & - & - & & - & - & - & - & - & - & - & - & - & - & - & - & - & - & - & - & - & - & - \\
\hline Inositol & - & - & - & & - & + & - & - & - & - & - & - & + & + & + & - & - & - & - & + & - & - & + \\
\hline D-Mannitol & - & + & + & & - & + & - & - & + & + & - & - & + & + & + & + & - & + & + & + & - & - & + \\
\hline $\begin{array}{l}\text { D-Sorbitol } \\
\text { methyl-aD- }\end{array}$ & - & + & + & & - & + & - & - & + & + & - & - & + & + & + & + & - & + & + & + & - & - & + \\
\hline $\begin{array}{l}\text { Mannopyranoside } \\
\text { methvl- } \alpha \text { D- }\end{array}$ & - & - & - & & - & - & - & - & - & - & - & - & - & - & - & - & - & - & - & - & - & - & - \\
\hline Glucopyranoside & - & - & - & & - & + & - & - & - & - & - & - & + & + & + & - & - & - & - & + & - & - & - \\
\hline & & & & & & & & & & & & & & & & & & & & & & & \\
\hline $\begin{array}{l}\text { AcetylGlucosami } \\
\text { ne }\end{array}$ & + & + & + & & + & - & + & - & + & + & + & + & - & - & - & + & - & + & + & - & + & + & - \\
\hline Amygdalin & - & - & - & & - & + & - & - & - & - & - & - & + & + & + & - & - & + & + & - & - & - & - \\
\hline Arbutin & - & + & + & & + & + & + & + & + & + & + & + & + & + & + & + & + & + & + & + & + & + & + \\
\hline
\end{tabular}


Table 4. Contd

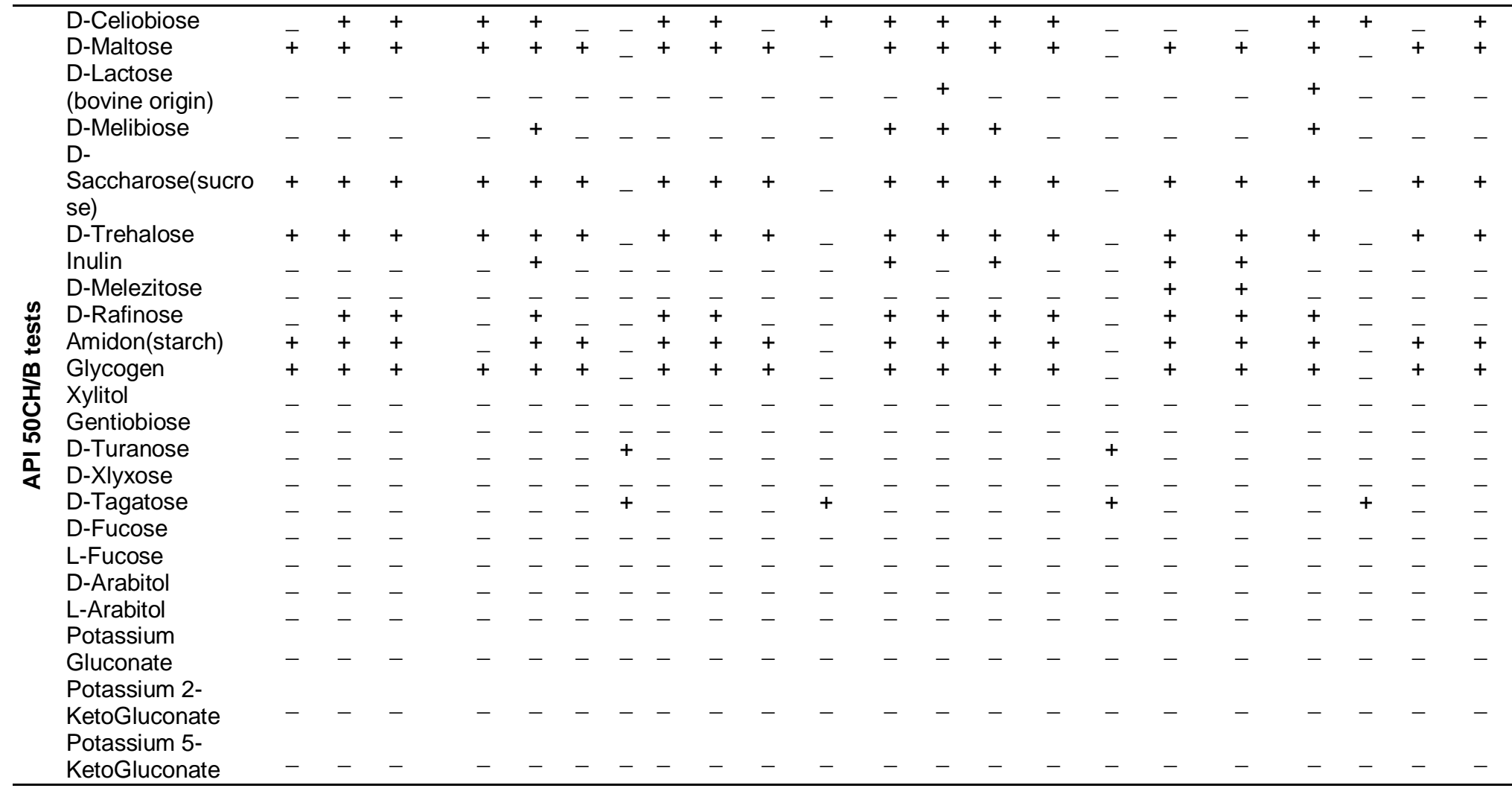

samples. Hasnaoui et al. (2010) reported in their study that samples with high sugar content (61$83 \%)$ and low water activity $(a w=<0.90)$ showed very low incidence of endogenous bacteria indicating poor conditions for their proliferation. Most bacteria cannot grow when water activity is reduced below 0.90 (Leistner and Rodel., 1975; Mossel, 1975; Sawaya et al., 1989). The Nature of solutes besides the water activity influences the growth of micro-organisms and hence plays an important role (Horner and Agnostopoulous,
1973). S. aureus was absent from all the varities except Rabea while E. coli was isolated from two varieties; Khodary and Naboot Sultan .In a study conducted by Aidoo et al. (1996), the pre-packed dates purchased in Glasgow contained high levels of coliform, yeasts and moulds and little or very low levels of $S$. aureus. It is apparent that the mesophilic aerobic bacterial contaminants were quite sensitive to the conditions of low temperature storage, low water activity, high sugar content in the fruits and the low level of oxygen in the packages so that the majority of them could not survive. All samples were found contaminated with molds, but the amount of contamination varied from one cultivar to the other. It can be understood from our results that variation of microbial contaminants, from date fruit of one variety to another could be due to the chemical composition of cultivar which makes them more susceptible to attack during harvest or processing.

Additionally, the hawkers in local open markets 
Table 5. Number of Bacterial Isolates (Count/plate/ml) identified from different varieties of date fruits and seeds.

\begin{tabular}{|c|c|c|c|c|c|c|c|c|c|c|c|c|}
\hline \multirow{2}{*}{ Isolates from fruits } & \multicolumn{12}{|c|}{ Date varieties screened } \\
\hline & Ajwa & Amber & Barhi & Khalas & Khodary & Mabroon & Mashrooq & Sukhari & Segae & Naboot Sultan & Naboot Seif & Rabeae \\
\hline B.thuringenesis & $\ldots$ & $\ldots$ & 2 & 20 & $\ldots$ & 60 & $\ldots$ & 1 & 1 & 3 & 2 & $\ldots$ \\
\hline B.subtilis & 20 & 11 & 50 & 50 & 15 & 10 & 10 & 20 & $\ldots$ & 5 & 2 & $\ldots$ \\
\hline B.stearothermo & $\ldots$ & $\ldots$ & 10 & 9 & 5 & 13 & 10 & $\ldots$ & $\ldots$ & 5 & 7 & 2 \\
\hline B.brevis & $\ldots$ & $\ldots$ & 5 & $\ldots$ & $\ldots$ & 15 & $\ldots$ & $\ldots$ & 6 & 2 & $\ldots$ & $\ldots$ \\
\hline B.mycoides & 3 & 8 & 1 & $\ldots$ & 5 & $\ldots$ & $\ldots$ & 10 & $\ldots$ & 5 & 3 & 2 \\
\hline B.meagaterium2 & 1 & 1 & 1 & 2 & $\ldots$ & $\ldots$ & 20 & 4 & 1 & 2 & 2 & $\ldots$ \\
\hline Staphylococcus aureus & $\ldots$ & $\ldots$ & $\ldots$ & $\ldots$ & $\ldots$ & $\ldots$ & $\ldots$ & $\ldots$ & $\ldots$ & $\ldots$ & $\ldots$ & 10 \\
\hline Escherishia coli & $\ldots$ & $\ldots$ & $\ldots$ & $\ldots$ & 1 & $\ldots$ & $\ldots$ & $\ldots$ & $\ldots$ & 1 & $\cdots$ & $\ldots$ \\
\hline \multicolumn{13}{|l|}{ Isolated from seeds } \\
\hline B. subtilis & $\ldots$ & $\ldots$ & $\ldots$ & $\ldots$ & $\ldots$ & 5 & $\ldots$ & $\ldots$ & $\cdots$ & 3 & $\ldots$ & $\ldots$ \\
\hline B.brevis & $\ldots$ & $\ldots$ & $\ldots$ & $\ldots$ & $\ldots$ & 15 & $\ldots$ & $\ldots$ & $\ldots$ & 1 & $\ldots$ & $\ldots$ \\
\hline
\end{tabular}

do not store them at refrigeration temperatures, further creating conditions required for the microbes to proliferate.

Another important fact is that date fruits contain some antimicrobial components. For example, some varieties contain up to $2.5 \%$ tannins (Al Hooti et al., 1997; Myhara et al., 2000) which have been reported to cause growth inhibition to many species of fungi and bacteria (Nelson et al., 1997; Ishida et al., 2006).

\section{Conclusion}

The climatic conditions as affected by temperature and humidity during growth, ripening, harvest and storage determine the extent of microbial infestation of the date palm fruits. Additionally, the nature of solute and the physiochemical changes occurring during ripening make the fruits more susceptible to microbial attack which could be the reason for variation in the fungal and bacterial load of different varieties. However the molds being more tolerant to extreme of conditions in this microenvironment were found in high numbers when compared to bacteria.

A very high incidence of $A$. niger from all fruits and seeds is to be noted. It can be concluded that dates palm fruits sold as loose fruits especially in local open markets of Saudi Arabia harbor many fungi and bacteria.

This level contamination with microbes in fruits, often consumed without washing, is a matter of concern. Hence methods that will curb the microbial infestation of fruits at harvest, post harvest and at storage conditions are required and should be made mandatory.

\section{ACKNOWLEDGEMENT}

This research project was supported by a grant from the "Research Center of the Female
Scientific and Medical Colleges", Deanship of Scientific Research, King Saud University.

\section{REFERENCES}

Abdulsalam KS, Ahmed AM, Ahmed AM (1991). The effect of three fungi and their combinations on the chemical constituents of two cultivars of date palm fruits. Emir. J. Agric. Sci. 3:81-95.

Aidoo KE, Tester RF, Morrison JE, Mac Farlane D (1996). The composition and microbial quality of prepacked dates purchased in Greater Glasgow. Int. J. Food Sci. Technol. 31:433-438.

Al-Hooti S, Sidhu JS, Qabazard H (1997). Physicochemical characteristics of five date fruit cultivars grown in the United Arab Emirates. Plant Foods Hum. Nutr. 50: 101-113.

Al Jasser MS (2010). Effect of storage temperatures on microbial load of some dates palm fruit sold in Saudi Arabia market. Afr. J. Food Sci. 4:359-363.

Al Kahtani M, El -Naggar MA, Omer SA, Eman M, Abdul Kareem MIA (2011). Effect of Toxic Fusarium monoliforme on some biochemical component of some Date Palm cultivars. Am. J. FoodTechnol. 6:730-741.

Al-Shahwan IM, El-Zaiat MM, Abo-Taleb EA, Al Fuhaid MS Abdden F, Al Quait S, Al-Harbi F (1997). First Saudi 
Symposium on Agricultural Sciences. pp. 182-183. http://faculty.ksu.edu.sa/53696/3/Fusarium spp 3.pdf.

Al-Sheikh H (2009). Date palm fruit spoilage and seed borne fungi of Saudi Arabia. Res. J. Microbiol. 4(5):208-213.

Al-Showiman SS, BaOsman AA (1992). Review of vitamins with special reference to dates. Saudi Pharm. J. 7:173-190.

Al Shuaibi A (2011). The econometrics of investment in date production in Saudi Arabia. Int. J. Appl. Econ. Finance. 5:177-184.

Atia MMM (2011). Efficiency of Physical Treatments and Essential Oils in Controlling Fungi Associated with Some Stored Date Palm Fruits. Aust. J. Basic Appl. Sci. 5:1572-1580.

Bokhary HA (2010). Seed-borne fungi of date-palm, Phoenix dactylifera L. from Saudi Arabia. Saudi J. Biol. Sci.17:327-329.

Cheesebrough M (2000). Microbiological Tests In: District Laboratory Practice in Tropical Countries. Cambridge: The Press Syndicate of the University of Cambridge and Tropical Health Technology. pp. 3545.

Collins CH, Lyne PM, Grange PM, Falkinham JO (2004). Microbiological Methods, 8th ed. Arnold publishers, London, UK.

Ellis MB (1971). Dematiaceous Hyphomycetes. I $^{\text {st }}$ Edn .,Common whealth Mycological Institute, Kew, Surrey ,UK., p. 608.

El-Hassni M, El-Hadrami A, Fouad D, Mohamad C, Barka EA, ElHadrami I (2007). Biological control of Bayoud disease in date-palm. Selection of microorganism inhibiting the causal agent, inducing defence reaction. Environment Experiment. Bot. 59: 224-234.

El-Sherbeeny MR, Saddik MF, Bryan FL (1985). Microbial profiles of foods served by street vendors in Egypt. Int. J. Food Microbiol. 2:355364.

FAO (UN Food and Agriculture Organization) (2008). "Date Palm." http://faostate.fao.org/ site/340/default.

Fayadh JM, Al Showiman SS (1990). A review on chemical composition of date palm (Phoenix dactylifera L.). J. Chem. Soc. Pak.12:84-103.

Hamad SH (2008). Microbial spoilage of date Rutab collected from the markets of Al-Hofuf City in the Kingdom of Saudi Arabia. J. Food Prot. 71:1406-1411.

Hamad SH (2012). The microbial quality of processed date fruits collected from a factory in al Hofuf city, Kingdom of Saudi Arabia. Emir.J. Food Agric. 24:105-112.

Hasnaoui A, Elhoumaizi MA, Asehraou A, Hakkou A (2010). Chemical composition and microbial quality of main varieties of dates grown in figuig oasis of Morocco. Int. J. Agric. Bio.12, 311-314.

Hayrettin O, Hatice IOBG, Guner $O$ (2012). Mycotoxin risks and toxigenic fungi in date, prune and dried apricot among Mediterranean crops; Phytopathologia Mediterranea.51:148-157.

Horner KJ, Agnostopoulous GD (1973). Combined effect of water activity, $\mathrm{pH}$ and température on the growth and spoilage potential of fungi. J. Appl. Bacteriol. 36: 427-436.

lamanaka BT, Taniwaki MH, Menezes HC, Vicente E, Fungaro MHP (2005). Incidence of toxigenic fungi and ochratoxin A in dried fruits sold in Brazil. Food Additives Contaminants. 22:1258-1263

International Seed Testing Association (ISTA) (1976). Seed Science and Technology 4:3-48.

Ishida K, De Mello JC, Cortez DA, Filho BP, Ueda-Nakamura T, Nakamura CV (2006). Influence of tannins from Stryphnodendron adstringens on growth and virulence factors of Candida albicans. J. Antimicrob. Chemother. 58:942-949.
Kader AA (2007). Recommendations for maintaining postharvest quality. Department of Plant Science, University of California,Davis.Available http://postharvest.ucdavis.edu/ProduceFacts/Fruit/Dates.shtml.

Leistner L, Rodel W (1975). The significance of water activity for microorganisms in meats. In: Duckworth, R.B. (ed.), Water Relations in Foods. Academic Press, New York. pp. 309-323.

Moore JE, Cherie M, Xu B, El Shilbly S (2011). Edible dates (Phoenix dactylifera L.), a potential source of Cladosporium cladosporioides and sporobolomyces roseus: implication for public health. Mycopathologica 54:25-28.

Mossel DAA (1975). In: Duckworth RB. (ed.). Water and Microorganisms in Foods-a Synthesis-in Water Relations of Foods. Academic Press, New York. pp. 347-361.

Mustafa Al, Hamad AM, Al-Kahtani MS(1983). Date varieties for jam production. In Proceedings of the First Symposium on the Date Palm in Saudi Arabia, King Faisal University, Al-Hassa ; Mars Publishing House: Riyadh, Saudi Arabia. pp. 496-501.

Myhara MR, Al-Alawi A, Karkalas J,Taylor MS (2000). Sensory and textural changes in maturing Omani dates. J. Sci. Food Agric. 80:2181-2185.

Nelson PE, Toussoun TA, Marasas WFO (1983). Fusarium species.An illustrated Manual for Identification. It $^{\text {st }}$ Edn,Pennsylvanis State University Press,University Park,New York,ISBN-10;0271003499.

Nelson KE, Pell AN, Doane PH, Giner - Chavez PS (1997). Chemical and biological assays to evaluate bacterial inhibition by tannins. J. Chem. Ecol. 23:1175-1194.

Ragab WSM, Ramadan BR, Abdel-Sater MA (2001). Mycoflora and aflatoxins associated with Saidy date affected by technological processes. The Second International Conference on Date Palms, UAE University, Al Ain, UAE, pp. 409-421

Ramirez C (1982). Manual and Atlas of Penicillia. Elsevier Biomedical press,Amerstadam, Netharlands .p. 874

Raper K, Fennel B (1965).The Genus Aspergillus .I It $^{\text {Et }}$. Wh.,Williams and Wilkins Co, Baltimore, Maryland.

Rygg GL (1956). Effect of temperature and moisture content on the rate of deterioration in Deglet Noor dates, Date Grower Inst. 33:8-11.

Sawaya WN, Khatchadourian $\mathrm{HH}$, Khalil JK, Al-Shalhat AF (1989). Processing of dates into date chutney. Proceedings of the 2nd Symposium on the Date Palm in Saudi Arabia, March 3-6, 1986, King Faisal University, Al-Hassa, Saudi Arabia, pp. 105-111.

Shinwari MA(1993). Date palm. In Encyclopaedia of Food Science,Food Technology and Nutrition; Macrae, R., Robinson, R.K., Sadler, M., Eds.; Academic Press: New York. pp.1300-1305. 